\title{
Technical Efficiency of Indonesian Commercial Banks: An Application of Two-Stage DEA
}

\author{
Tessa Vanina Soetanto and Ricky \\ Faculty of Economics, Petra Christian University \\ Jl. Siwalankerto 121-131 Surabaya 60263 \\ E-mail: tessa@peter.petra.ac.id; ricky@peter.petra.ac.id
}

\begin{abstract}
ABSTRAK
Penelitian ini mempergunakan metode DEA (Data Envelopment Analysis) untuk mengetahui efisiensi teknis (technical efficiency) bank-bank komersial di Indonesia. Penelitian ini mengambil data pada tahun 2004-2009 dengan menggunakan pendekatan intermediasi (intermediation approach). Hasil-hasil penelitian menunjukkan bahwa bank-bank komersial di Indonesia telah mengalami peningkatan dalam efisiensi teknis (technical efficiency), rata-rata sebesar 10.5\%. Lebih lanjut, hasil studi juga memberikan konfirmasi jika perbankan nasional mengalami ketidakefisienan secara skala (scale inefficiency) yang lebih besar dibandingkan dengan ketidakefisienan secara teknis murni (pure technical efficiency). Dilihat dari kepemilikannya, bank-bank pemerintah menunjukkan efisiensi yang sempurna selama masa studi dibandingkan dengan bank-bank swasta. Hasil terakhir yang didapat dari regresi Tobit menunjukkan bahwa skala aset dan resiko likuiditas dapat membantu peningkatan efisiensi bank, sedangkan kondisi yang sebaliknya terjadi untuk profitabilitas.
\end{abstract}

Kata Kunci: DEA, efisiensi teknis, efisiensi teknis murni, efisiensi skala, bank komersial

\begin{abstract}
This paper uses data envelopment analysis (DEA) to investigate the technical efficiency of the Indonesian commercial banks over the period 2004-2009 using intermediation approach. The analysis is conducted based on common frontier of duration of study and ownership of the banks, namely state-owned banks and private banks. Then Tobit regression model is used to examine the influence of internal factors as bank characteristics to efficiency scores. The results of DEA show that Indonesian commercial banks could improve their technical efficiency by $10.5 \%$ on average and the scale inefficiency is dominating over pure technical inefficiency. The commercial state-owned banks are showing perfect efficiency during the period of study, and proven to be more efficient compared to the commercial private banks. Finally Tobit regression is revealing that higher asset scale and liquidity risk increase the efficiency of the bank, while the profitability is on the contrary.
\end{abstract}

Keywords: DEA, technical efficiency, pure technical efficiency, scale efficiency, commercial banks

\section{INTRODUCTION AND DEVELOPMENT OF INDONESIAN BANKING INDUSTRY}

Banking performance is one of the important pillars in developing a country. The intermediary function of a bank determines the flow of fund which is vital for economic competitiveness. Shenkar \& Luo (2004) wrote that internal determinants for country competitiveness are Education (including Science and Technology), Economics (Macroeconomis Soundness), Finance and Internationalization. Later the two professors in International business explained the important of strong banking system is so important for stability. Schwab (2010) from World Economic
Forum through Global Competitiveness Index stated that macroeconomic environment and financial market development are two out of twelve pillars of country competitiveness.

The importance of Bank as the facilitator of economic development in Indonesia is getting more. According to Bank Indonesia (BI), banks in Indonesia must perform four important functions: performing as financial intermediary, payment system support, setting and implementing monetary policy, and ensuring financialstability. It is believed that sound, transparent and prudent banking system is the prerequisite for further economic development of a nation (Indonesia Banking Booklet, 2010). In relation 
with those idealism, BI has launched the grand design for banking industry namely Indonesian Banking Architecture (API).

The authority must perform well simply because bank is still the primary option for people in placing their fund in Indonesia. Bank Indonesia stated that per June 2010 bank's asset is $80 \%$ of the total asset of finance institutions in Indonesia (Kajian Stabilitas Keuangan, 2010). Banks in Indonesia, based on the statute, can be divided into commercial banks and rural banks (Bank Perkreditan Rakyat/BPR). The differences are commercials banks can create demand deposits while BPR cannot do the same and have limited scope of their operational activities. Then in running the business, commercial bankscan be categorized into the ones that adopt conventional approach or based on Islamic principles (Syariah) or both and BPR can only adopt one of them (Bank Indonesia).In this research, the focus of the study is commercial banks which are adopting the conventional approach due to the fact that total assets managed by commercial banks are reaching $98 \%$, while the remains are managed by BPR (IBS, 2010).

In Indonesia the past decade has witnessed merger and acquisitions, changes in regulations learning from the bitterness of Asian Financial Crisis. Theoretically, bank mergers and acquisition could broaden the product mix and reduce costs. Large size capital and asset are crucial for a bank to become an efficient, competitive and powerful bank. In May 2010, credit channeled through commercial bank raised $14.3 \%$ to Rp. 1.492 trillion compared the previous year and capital adequacy ratio is reaching $18.9 \%$. The same year also mark that liquidity hits $\mathrm{Rp}$ 307 trillion (Bisnis Indonesia, 2010:68). Per May 2010, the number of commercial banks in Indonesia is 122 banks thatconsists of 4 state-owned banks, 35 foreign and 31 non foreign exchange commercial banks, 26 regional development banks, 16 joint venture banks and 10 foreign owned banks. Among those banks, $75 \%$ of assets are being held by stateowned banks and foreign exchange commercial banks (IBS, 2010). That is the reason of sample selection used in this study.

This research has two objectives, first is to evaluate the performance of Indonesian commercial banks by assessing their technical efficiency and to explain the corresponding factors influencing it. Given the nature of the industry, the internal factors represented on the banks' financial statement will be used for the research. The paper is organized as follows. It starts with introductory and brief explanation about recent development of banking industry, particularly commercial banks in Indonesia. Then it continues with literature review about DEA application in banking industry worldwide and in Indonesia. The next section will review the DEA (methodology) along with the data and variables used in the research. Finally the final section will display and discuss the results coherent with the research objectives.

\section{LITERATURE REVIEW}

Over the last years, several papers have examined the efficiency of banks using Data Envelopment Analysis (DEA) combined with other methods such as Malmquist Index and Neural Networks. Galagedera \& Edirisuriya (2004) investigate efficiency using DEA and productivity growth using Malmquist index in a sample of Indian commercial banks over the period 1995-2002. The rate of increase in technical efficiency though small is likely to be due to scale efficiency compared to managerial efficiency. In general, smaller banks are less efficient and highly DEA-efficient banks have a high equity to assets and high return to average equity ratios. There has been no growth in productivity in banks'private sector where as the public sector banks appear to demonstrate a modest positive change through 1995-2002.

Al-Tamimi (2006) used DEA to identify the relatively best-performing banks and relativelyworst-performing banks in the United Arab Emirates during the period 1997-2001. It also seeks to identify banks' efficiency scores and ranks. The main findings of this study are most of the UAE commercial banks appear inefficient and the national banks are relatively more efficient than the foreign banks. Also two traditional ratios namely, loans to deposits, and loans to total assets indicate that the UAE commercial banks somehow did not use the available resources properly.

Pasiouras et al. (2007) used two stage procedure to examine the cost of efficiency of Greek cooperative banks. The samples consist of 16 banks over the period 2000-2004 and the study employed DEA to estimate technical, allocative and cost efficiency for each bank in the sample. Then, Tobit regression was being used determine the impact of internal external factors on bank's efficiency. The results of DEA indicate that Greek cooperative banks could improve their cost efficiency by $17.7 \%$ on average as well as that the dominant source of cost inefficiency is allocative rather than technical. The results of Tobit regression indicate that size has a positive impact on all measures of efficiency while impact of capitalization, branches and ATMs depends on the efficiency measure and whether there is control over market conditions or not. While GDP per capita has 
negative and significant impact on all measures of efficiency, also unemployment rate has negative and significant impact on technical and cost efficiency although not on allocative efficiency.

Saad \& Moussawi (2009) used two approaches to assess the cost efficiency of Lebanese commercialbanks: a nonparametric method, Data Envelopment Analysis, and a parametric method, StochasticFrontier Analysis (SFA). There are 43 commercial banks over a period from 1992 to 2005. Later on, an econometric model was used to investigate the determinants of the efficiency scores of Lebanese banks using financial and economic explanatory variables. The result shows higher efficiency scores with the SFA compared with the DEA and suggest a clear efficiency growth in the Lebanese banking sector. Furthermore, internal factors and the economic environment seem to contribute significantly to the evolution of theefficiency scores

Usman et al. (2010) employed DEA to a panel of commercial banks operating in Pakistan for a period of 2001-2008 to measure the technical efficiency of them. Technical efficiency is being divided into pure technical and scale components. The banks are divided into three categories for analytical purposes: state owned banks, domestic private banks and foreign owned banks. The result shows that pure technical efficiency contributes more towards technical efficiency and banks are faced with serious scale problems. Further it is found that foreign owned banks to be the most efficient and domestic private banks are found to be the least efficient. Chan (2011) examined the technical efficiency of commercial banks in China during 2001-2007 by employing DEA. Technical efficiency is furthered decomposed into pure technical and scale efficiency to determine the sources of inefficiency of the commercial banks in China. Results found that commercial banks in China on average are relatively technically inefficient.

To date there has been relatively little research conducted in the efficiency of Indonesian banking system. The research were being done by Permono \& Darmawan (2000), Hadad et al. (2003), Hadad et al. (2008), Putri \& Lukviarman (2008), Suseno (2008) and Suzuki \& Sastrosuwito (2011) is using nonparametric approach, DEA, to measure the efficiency of Indonesian banks from period of 1996-2003 and the merger affect on the bank performance. Input/ ouput measurement was using asset approach in Altunbas et al. (2001). The conclusion is the non foreignexchange private banks are the most efficient during year of 2001-2003 compare to other banks and merger does not always increase the efficiency of the bank.

Suseno (2008) measures the efficiency of Indonesian Islamic bankingin the period 1999-2004 and uses DEA to analyze 10 banks as sample. It analyzes the relationship between efficiency score and the scale ofbanking industry using regression based on intermediation function.It found thatfirst, Islamic banking in Indonesia is efficient enough during the period and reached an average of inefficiency about $7 \%$. Second, there is no significant difference between Islamic bank and general bank that has Islamic banking unit. Last, there is an increasing efficiency about 2.3 percent per year in Islamic banking during the year of study. The most recent research also using DEA conducted by Suzuki \& Sastrosuwito (2011) which the samples were being grouped into four groups based on ownership (government owned, privatelyowned, joint venture and foreign-owned). Suzuki confirmed that during 1994-2008, the efficiency of the Indonesian banking sector was relatively high, with the mean of overall industry 0.866 . Later he explained that productivity of the Indonesian commercial banks during the mentioned period was due to technological change than technical efficiency change. While this study examines the technical efficiency of Indonesian commercial banks in doing the intermediary role during the year of 2004-2009 and the relationship to internal factor of banks' characteristic that has not been covered in the previous studies.

\section{RESEARCH METHODOLOGY}

To examine the efficiency of the banks, there are some approaches that can be used from a methodological perspective, include the parametric and nonparametric approaches such as Stochastic Frontier Analysis (SFA), Thick Frontier Approach (TFA), Distribution Free Approach (DFA), Free Disposal Hull and Data Envelopment Analysis (DEA). These efficiency measurements differ primarily in how much shape is imposed on the frontier and the distributional assumptions imposed on the random error and inefficiency (Berger \& Humphrey, 1997). In the research literature, both parametric and nonparametric approaches have been widely used but there is no consensus which of these approaches is superior (Berger \& Humphrey, 1997).

The main non-parametric approach is Data Envelopment Analysis. DEA is a mathematical programming approach for the development of production frontiers and the measurement of efficiency relative to the development frontiers (Charnes et al., 1978).

It is also able in handling multiple inputs as well as multiple outputs. DEA is considered as a deterministic function of the observed variables, and no specific functional form is required. Other main 
advantages of using DEA are that it performs well with only small number of observations and it does not require any assumption to be made about the distribution of inefficiency. Avkiran (1999) stated that DEA allows the researchers to choose any kind of input and output, regardless of different measurement units (Sufian, 2007). On the other hand, the shortcomings of DEA are that it assumes data to be free of measurement error and is sensitive to outliers.

DEA uses the term Decision Making Unit (DMU) to refer to any entity that is to be evaluated in terms of its abilities to convert inputs into outputs. If there are n DMUs to be evaluated then each DMU consumes varying amounts of $\mathrm{m}$ different inputs to produce s different outputs. Specifically, DMUj consumes amount xijof input $\mathrm{i}$ and produces amount yrjof output $\mathrm{r}$. We assume that $x \mathrm{ij} \geq 0$ and $y \mathrm{rj} \geq 0$ and further assume that each DMU has at least one positive input and one positive output value.

The original formulation of the DEA model introduced by Charnes et al. (1978), denoted CCR. The ratio of outputs to inputs is used to measure the relative efficiency of the DMUj $=$ DMUOto be evaluated relative to the rations of all of the $j=$ $1,2, \ldots, n$ DMU. This basic DEA model implied the assumption of Constant Returns to Scale (CRS). Using Charnes-Cooper transformation and dual formulation under CRS, then:

$\theta^{*}=\operatorname{Minimum} \theta$

Subject to

$\sum_{j=1}^{n} \lambda_{j} x_{i j}-\theta x_{i 0} \leq 0 \quad i=1, \ldots, m$

$\sum_{j=1}^{n} \lambda_{j} y_{r j}-y_{j 0} \geq 0 \quad r=1, \ldots, s$

$\lambda \mathrm{j} \geq 0 \quad \forall j$

The optimal solution, $\theta^{*}$, yields an efficiency score for a certain DMU. The process is repeated for each $\mathrm{DMU}_{\mathrm{j}}$. DMUs for which $\theta^{*}<1$ are inefficient, while DMUs for which $\theta^{*}=1$ are boundary points or efficient. This model is sometimes referred to as the "Farrell model" (Cooper et al., 2004).

CRS is appropriate only when all firms are operating at an optimal scale. A bank exhibits constant return to scale if a proportionate increase or decrease in inputs or outputs move the bank along or above the frontier. The efficiency measure derived from the model reflects the technical efficiency (TE).

DEA has proven to be a valuable tool for strategic, policy and operational problems, particularly in the service sector and nonprofit sectors. Its feature is adopted to provide an analytical, quantitative comparison tool for measuring relative efficiency
(Barr, 2002). Technical efficiency (TE) refers to ability to produce the maximum outputs at a given level of inputs (output-oriented), or ability to use the minimum level of inputs at a given level of outputs (input-oriented).

Due to imperfect competition or constraint in finance then not all banks are able to operate at the optimal scale. In that condition, Banker et al. (1984) suggested the use of Variable Return to Scale (VRS), denoted as BCC hereafter that allows the calculation of efficiency leads to decomposition of technical efficiency into scale (SE) and pure technical efficiency (PTE) components. The BCC model is (1) together with additional constraint that captures return to scale characteristics.

$\sum_{j=1}^{n} \lambda_{j}=1$

Then, the efficiency estimates obtained in the BCC model is net of the contribution of scale economies and therefore is referred to as 'pure' technical efficiency and also as the managerial efficiency.

A DEA model can be constructed either to minimize inputs or maximize outputs. An input orientation aims at reducing the input amounts as much as possible while keeping at least the present output levels, while an output orientation point towards at maximizing output levels without increaseing use of inputs (Cooper et al., 2004). Kumbhakar \& Lozano-Vivas (2005) stated that the focus on costs in banking and the outputs are prone to be demand determined means that input-oriented models are most commonly used (in Sufian, 2007).

Scale Efficiency (SE) can be defined as the proportional reduction of input use to be obtained under CRS. It measures whether a bank produces at an optimal size of scale (Hauner, 2005). PTE is showing how well bank's managerial and marketing skills in using its inputs in order to maximize outputs. A measure of scale efficiency (SE) is simply the ratio of TE and PTE. TE is determined by economies of scale due to the size of the bank (SE) and managerial efficiency (PTE) (Hermes \& Vu, 2008 and Tahir et al., 2009). According to Yin (1999), the type of efficiency measured depends on the data availability and appropriate behavioral assumptions (in Galagedera et al., 2004).

\section{Data and Variables}

The data used for this research were collected from various sources: Annual Reports from the website of banks, Bank Indonesia database, Indonesian Stock Exchange database. Our sample is consisting of 20 domestic commercial banks (4 state- 
owned banks and 16 private-owned banks) during the period from 2004 to 2009, totaling 120 observations. Berger \& Mester (1997) concur with De Young (1997) that a six-year period reasonably adequate of not considered as too short or too long period (in Barry et al., 2008)

Berger \& Humphrey (1997) commented on the difficulty of variable selection in performance of banks using DEA since there is no perfect approach on the explicit definition and measurement of banks' input and outputs. The primary approaches in measureing banks' input and outputs are the production approach and intermediation approach (Barr, 2002; Galagedera \& Edirisuriya, 2004; Hermes \& Vu, 2008; Saad \& Mousawi, 2009). As in Paradi \& Schaffnit (2004), the first approach assumes banks act as institutions providing fee-based products and services to customers using various resources. This approach used for studying cost efficiency, since it considers the operating costs of banking. While the second approach looks at the bank as financial intermediaries who collect funds in the form of deposits and lend them out as loans or other assets earning an income. This approach is used for studying the organizational efficiency and economic viability of banks.

In this research we are adopting intermediation approach because of two reasons. First, based on Bank Indonesia, the banks in Indonesia have the functions of financial intermediary that take deposits from surplus units and channel financing to deficit units (Indonesian Banking Booklet, 2010). Second based on Berger \& Humphrey (1997) stated that production approach is somewhat better for evaluating the efficiencies of branches of financial institutions.

In the intermediation approach, we use three inputs: customer deposits, fixed assets, and number of employees and three outputs: loans, other earning assets (consist of securities, deposits with other banks, others) and non-interest income (Paradi \& Schaffnit, 2004; Pasiouras et al., 2007; Tahir \& Haron, 2009; Saad \& Mousawi, 2009).

The data processing is performed using DEA Frontier program developed by Zhu (2009). Using intermediation approach to calculate technical efficiency (TE) of the sample of banks obtained through under CRS (input-oriented version of DEA). Continued by decomposing TE into pure technical efficiency (PTE) resulted through under VRS (inputoriented version of DEA) and the scale of efficiency (SE).

Then the technical efficiency score (TE) during the period of study are regressed on a number of explanatory variables based on internal factors. Those internal factors as banks characteristics are ASSETS measured by the natural logarithm of total assets to represent the size, EQAS calculated as equity capital to total assets is a measure of capital strength, ROA measured by return on assets to assess profitability, and LOANS calculated as the loan to assets to represent liquidity risk (Altunbas et al. in Havrylchyk, 2006). As the scores of efficiencies are bounded between zero and unity then it is required to use limited dependent variable model which is called Tobit Regression model as in Drake (2006), Havrylchyk (2006), Hauner (2005), Pasiouras (2008). Heterocedascity can occur when estimated parameters are used as dependent variables in the second stage analysis (Saxonhouse in Pasiouras et al., 2007) and based on Hauner (2005) then Huber/White standard errors and covariates are calculated.

Table 1 below presents the descriptive statistics of banks' inputs and outputs used in this study and Table 2 shows the explanatory variables used in the Tobit Regression model. There is a marvelous development of Indonesia commercial banks from year of 2004-2009 as can be seen in the amount of deposits, loans, and other earning assets. The amount of deposits is getting high remarkably in the year of 2009 which is twice of beginning of the research period. That shows that the capital of commercial banks are getting stronger since deposits is the biggest source of fund, while credit channeling process is highly improved as well that can be seen from the amount of loans which is leading to good profitability, shown by average Return on Assets (ROA) is equal to 1.996. However, looking at the amount of standard deviation (1.202), it shows that there is a gap in the commercial banks in term of profitability.

Table1. Commercial Bank's Input and Output Variables 2004-2009 (in Rp Billion, except number of employees)

\begin{tabular}{lcrrrrrr}
\hline Variable & & $\mathbf{2 0 0 4}$ & $\mathbf{2 0 0 5}$ & $\mathbf{2 0 0 6}$ & $\mathbf{2 0 0 7}$ & $\mathbf{2 0 0 8}$ & $\mathbf{2 0 0 9}$ \\
\hline Deposits & X1 & 732.75 & 831.13 & 933 & $1,098.571,320.071,502.57$ \\
Fixed Assets & X2 & 19.84 & 21.20 & 21.19 & 21.65 & 24.09 & 25.04 \\
\# of Employees & X3 & 159,672 & 174,000 & 180,568 & 188,027 & 200,084 & 201,099 \\
Loans & Y1 & 408.13 & 498.28 & 558.56 & 704.95 & 951.25 & $1,048.09$ \\
Other Earning & Y2 & 433.93 & 446.67 & 592.60 & 630.21 & 561.45 & $1,069.34$ \\
Assets & & & & & & & \\
$\begin{array}{l}\text { Non Interest } \\
\text { Income }\end{array}$ & Y3 & 12.55 & 11.64 & 13.47 & 17.08 & 20.98 & 26.53 \\
\hline
\end{tabular}

$\mathrm{X}$ : Inputs, Y : Outputs

Table 2. Tobit Regression Exploratory Variables

\begin{tabular}{lrrrr}
\hline & LNASSETS & EQAS & \multicolumn{1}{c}{ ROA } & LOANS \\
\hline Mean & 10.211 & 0.1006 & 1.996 & 0.5538 \\
Standard Deviation & 1.529 & 0.039 & 1.202 & 0.1273 \\
\hline
\end{tabular}

LNASSETS: natural logarithm of total assets; EQAS: equity to total assets; ROA: return on assets (\%); LOANS: loan to assets 


\section{RESULTS AND ANALYSIS}

The discussion of the results on the efficiency of commercial banks in Indonesia is structured in 2 parts. First, the efficiency of commercial banks in Indonesia is examined each year. Then it continued with the analysis which is based on the ownership, stated-owned banks and private banks. Second, to investigate the determinants of efficiency we construct an econometric model with $\mathrm{TE}$ as dependent variable.

Table 3 presents the results from the model that correspond to input/outputs selected by examining yearly and during the years of study. The average TE obtained by intermediation approach ranges between 0.804 (2004) and 0.929 (2006), with an overall mean over the entire period equal to 0.895 which indicates that banks could have saved $10.5 \%$ of inputs in order to produce the same level of output. Carefully examined the period of study, particularly in the year of 2004, there is a bank with the lowest TE, 0.327 and the highest standard deviation, 0.207. It shows there is a gap between commercial banks in Indonesia in terms of technical efficiency in that year. However the dispersion is getting smaller in the later years and achieving 0.135 in the year of 2009. Examining the result carefully, it shows that the average TE during 2004-2007 keep increasing but it is declining during the last two years. The possible reason for this phenomenon could be global financial crisis that hit the world during those years.

Table 3. DEA Results-Technical Efficiency (TE)

\begin{tabular}{lcccccc}
\hline & $\mathbf{2 0 0 4}$ & $\mathbf{2 0 0 5}$ & $\mathbf{2 0 0 6}$ & $\mathbf{2 0 0 7}$ & $\mathbf{2 0 0 8}$ & $\mathbf{2 0 0 9}$ \\
\hline Mean & 0.804 & 0.913 & 0.929 & 0.926 & 0.908 & 0.887 \\
S.D & 0.207 & 0.116 & 0.101 & 0.144 & 0.119 & 0.135 \\
Median & 0.853 & 0.960 & 0.994 & 1.000 & 0.988 & 0.927 \\
Min & 0.327 & 0.623 & 0.709 & 0.507 & 0.653 & 0.584 \\
Max & 1.000 & 1.000 & 1.000 & 1.000 & 1.000 & 1.000 \\
\hline
\end{tabular}

Table 3 presents the results of decomposition of Technical Efficiency (TE) based on CRS model into Pure Technical Efficiency (PTE) and Scale Efficiency (SE) based on VRS model. The average PTE ranges between 0.92 (2004) and 0.98 (2006, 2007), with an overall mean over the entire period equal to 0.959 while average SE ranges between 0.88 (2004) and 0.95 (2006-2007 and 2009), with an overall mean over the entire period equal to 0.934 . Hence, between 2004 and 2009 commercial banks could improve pure technical efficiency by $4.1 \%$ and scale efficiency by $6.6 \%$ on average.

The average of PTE during the period is higher than the average of TE. These results are in line with Banker et al. (1984) stated that technical efficiency scores obtained under VRS (PTE) are higher than or equal to those obtained under CRS (TE). While in comparison to scale efficiency, there is indication which PTE contributes more towards TE during the years of study except in the year of 2009 and the bank inefficiency is attributed to scale rather than managerial efficiency. This result is in line with Usman et al. (2010) in Pakistan, Tahir et al. (2009) and Sufian (2010) in Malaysia and in contrast with Galadegera \& Edirisuriya (2004) in India, also Chan (2011) in China.

Table 3. Technical Efficiency (Mean)-Decomposition into Pure Technical Efficiency and Scale Efficiency

\begin{tabular}{lccccccc}
\hline & 2004 & 2005 & 2006 & 2007 & 2008 & 2009 & Mean (2004-2009) \\
\hline PTE & 0.92 & 0.97 & 0.98 & 0.98 & 0.97 & 0.94 & 0.959 \\
SE & 0.88 & 0.94 & 0.95 & 0.95 & 0.94 & 0.95 & 0.934 \\
TE & 0.80 & 0.91 & 0.93 & 0.93 & 0.91 & 0.89 & 0.895 \\
\hline
\end{tabular}

As can be seen in Table 4, the result of TE based on the ownership shows that state-owned bank always be efficient every year except in 2005 and overall it is achieving 0.8992 efficiency score. While private banks are not as technically efficient as state-owned banks, however it is changing to a better efficiency level from year to year. Overall, the mean of TE from private banks is 0.7812 , lower than state-owned banks and that denotes that private banks could have saved $21.88 \%$ of inputs in order to produce the same level of output. This finding is showing the same result with Hadad et al. (2003), Hadad et al. (2008), and Suzuki $\&$ Sastrosuwito (2011).

Table 4. Technical Efficiency (Mean)-Based on Ownership

\begin{tabular}{lccccccc}
\hline \multicolumn{7}{c}{ State-Owned } \\
\hline Mean & $\mathbf{2 0 0 4}$ & $\mathbf{2 0 0 5}$ & $\mathbf{2 0 0 6}$ & $\mathbf{2 0 0 7}$ & $\mathbf{2 0 0 8}$ & $\mathbf{2 0 0 9}$ & All \\
Std. Deviation & 1 & 0.9998 & 1 & 1 & 1 & 1 & 0.8992 \\
$\mathbf{N}$ & 0 & 0.0003 & 0 & 0 & 0 & 0 & 0.1087 \\
& 4 & 4 & 4 & 4 & 4 & 4 & 24 \\
\hline \multicolumn{7}{c}{ Private } \\
\hline Mean & 0.8200 & 0.9285 & 0.9226 & 0.9262 & 0.8949 & 0.9096 & 0.7812 \\
Std. Deviation & 0.186 & 0.116 & 0.1066 & 0.1595 & 0.1237 & 0.13 & 0.1714 \\
N & 16 & 16 & 16 & 16 & 16 & 16 & 96 \\
\hline
\end{tabular}

Table 5 is pointing out the result of decomposition of TE into PTE and SE based on the ownership, it is clearly seen that in every year stateowned banks are efficient from the perspective of scale and managerial efficiency. There is no change happening with the efficiency except in the year of 2005. Whilst the cause of inefficiency that is happened in the case of private banks is scale. The results for decomposition of state-owned banks and private banks during all years exhibit in the opposite, pure technical inefficiency dominates scale ineffi- 
ciency. This implies that state-owned banks could improve PTE by $6.24 \%$ and SE by $4.35 \%$, as private banks could improve PTE by $13.32 \%$ and SE by $9.33 \%$.

Table 5. Pure Technical Efficiency and Scale Efficiency (Mean) -Based on Ownership

\begin{tabular}{lccccccc}
\hline $\begin{array}{l}\text { Pure Technical } \\
\text { Efficiency }\end{array}$ & $\mathbf{2 0 0 4}$ & $\mathbf{2 0 0 5}$ & $\mathbf{2 0 0 6}$ & $\mathbf{2 0 0 7}$ & $\mathbf{2 0 0 8}$ & $\mathbf{2 0 0 9}$ & All \\
\hline State-Owned & 1 & 1 & 1 & 1 & 1 & 1 & 0.9376 \\
Private & 0.9500 & 0.9766 & 0.9772 & 0.9719 & 0.9626 & 0.9614 & 0.8668 \\
\hline Scale Efficiency & $\mathbf{2 0 0 4}$ & $\mathbf{2 0 0 5}$ & $\mathbf{2 0 0 6}$ & $\mathbf{2 0 0 7}$ & $\mathbf{2 0 0 8}$ & $\mathbf{2 0 0 9}$ & All \\
\hline State-Owned & 1 & 0.9998 & 1 & 1 & 1 & 1 & 0.9565 \\
Private & 0.8683 & 0.9501 & 0.9447 & 0.9520 & 0.9319 & 0.9475 & 0.9067 \\
\hline
\end{tabular}

Table 6. Tobit Regression Result

\begin{tabular}{lccc}
\hline & \multicolumn{3}{c}{ Technical Efficiency (TE) } \\
\cline { 2 - 4 } & Coefficient & t-values & p-values \\
\hline Constant & 0.1687 & 1.36 & 0.178 \\
LNASSETS & 0.0506 & 6.06 & $0.000^{*}$ \\
EQAS & 0.3212 & 1.21 & 0.230 \\
ROA & -0.0261 & -2.57 & $0.012^{*}$ \\
LOANS & 0.4139 & 4.6 & $0.000^{*}$ \\
\hline
\end{tabular}

LNASSETS: natural logarithm of total assets; EQAS: equity to total assets; ROA: return on assets (\%), LOANS: loan to assets.

*Statistically significant at the $5 \%$ level and at the $10 \%$ level

As can be seen in Table 6, result of Tobit Regression shows that the model fit, where asset size (LNASSETS), capital strength (EQAS), profitability (ROA) and liquidity risk (LOANS) are statistically significant explaining Indonesian commercial banks efficiency from 2004-2009. It means the efficiency in performing the intermediary role is being explained well by the independent variables. Despite the expected fitness of model, capital strength is not significant in explaining the changes in technical efficiency.

Asset size is positively influencing the efficiency which similar result also being exhibited by Pasiouras et al. (2007), Saad \& Moussawi (2009). The relationship can be explained with the fact that Indonesian banks experienced major mergers and acquisitions which make them becomes bigger yet also being driven to be efficient by the acquiring bank. The phenomena of Banking Mergers and Acquisitions are due to the Government's Regulation through Indonesian Banking Architecture. In 2008, IBA stated that Banks must have minimum capital of IDR 80 Billions. Acquiring Banks like OCBC (NISP), CIMB (Niaga), Maybank (BII) have implemented specific banking practices including technology that forces the banks to be more efficient. In other words, the banks become bigger in asset's size yet have to change their business practices. Berger et al. (1999) also have pointed out that bank mergers may lead to changes in efficiency.
The highest positive influence for the technical efficiency is from the liquidity risk represented by the ratio between loans to total asset. The higher the liquidity risk the higher also the bank's technical efficiency. Liquidity risk in banks is a trade-off between bank intermediary performance role and having a crisis of cash. Giving more loans means facing risk for a potential return. Similar results were also being shown by Pasiouras (2008) and Isik \& Hasan (2003).

The data on bank's credit utilization produced by BI (Infobank Magazine, 2010) indicated that the credit is more for short-term orientation for consumption and working capital rather than long-term orientation of investment. Credit for investment is only $19.75 \%$ compared to consumption $(28.66 \%)$ and working capital $(51.59 \%)$. The trend of credit's growth indicated that credit for consumption was growing by $23 \%$ compared to both investment and working capital growth that was $19 \%$. This is a strong indicator that companies in Indonesia doubt the role of government in sustaining long-term development in Indonesia.

The paradoxical finding stated that technical efficiency is negatively correlated with bank's profitability, while in the Pasiouras (2008), and Saad \& Moussawi (2009) efficiency is being influenced positively by bank's profitability. However the negative correlation is explainable in the context of Indonesia's banking industry since during the years of 2004-2009 is being fulfilled with facts which Bank Indonesia was trying to increase the Loan to Deposit Ratio (LDR) by imposing Reserve Requirement (RR) regulation. It stated that banks with LDR lower than 90\% must add certain Reserve Requirement (RR) equal to $1 \%$ of the third party funds (ICRA Indonesia, 2010). It is a strong indicator that returns earned by banks in Indonesia were not coming from performing intermediary role to the business for the sake of economic growth but acquiring the return from other activities such as placing their fund in Bank Indonesia, financial market investments and credits for consumption.

The fact that capital strength has nothing to do with technical efficiency, the same with Havrylchyk (2006) in Poland, is explained again by the fact that the capital strength is much due to the mergers and acquisitions during 2004-2009. The new banks were meeting the government's requirement for minimum capital but yet they still need to be driven to increase their intermediary performance. This is being confirmed by the fact that from 2005-2009 credit for micro business was growing only $15 \%$, while for small business was 25\% (Investor Magazine, February 2011). 


\section{CONCLUSION}

As the importance of bank as the facilitator of economic development in Indonesia is getting more and one of the important function of bank in Indonesia is acting as financial intermediary then evaluating the performance of Indonesian commercial banks becomes crucial. This paper is assessing the technical efficiency of Indonesian commercial banks from the period of 2004-2009 from the perspective of intermediary role. Using the intermediation approach, three inputs have been used: customer deposits, fixed assets, and number of employees and three outputs: loans, other earning assets (consist of securities, deposits with other banks, others) and non-interest income to calculate the technical efficiency (TE) score which later being broken down into pure technical efficiency (PTE) and scale efficiency (SE). The analysis is being conducted based on Indonesian commercial banks efficiency scores per year and on the average during the period of study. Then it continued by seeing the result from the perspective of the ownership of the banks, government owned and private. Later, we used Tobit analysis to regress the technical efficiency scores obtained from the first stage over several internal variables reflecting bank characteristic and strategic decisions.

The results indicate that the average TE obtained by intermediation approach shows overall mean over the entire period equal to 0.895 which indicates that banks could have saved $10.5 \%$ of inputs in order to produce the same level of output. Hence, between 2004 and 2009 commercial banks could improve pure technical efficiency by $4.1 \%$ and scale efficiency by $6.6 \%$ on average. The result of TE based on the ownership shows that state-owned bank always be efficient except in year of 2005 and overall it is achieving $89.92 \%$ efficiency score. While private banks are not as technically efficient as state-owned banks and denotes that private banks could have saved $21.88 \%$ of inputs in order to produce the same level of output. Furthermore, the decomposition of TE into PTE and SE based on the ownership is clearly seen that in every year state-owned banks are efficient from the perspective of scale and managerial efficiency and the state-owned banks could improve PTE by $6.24 \%$ and SE by $4.35 \%$, as private banks could improve PTE by $13.32 \%$ and SE by $9.33 \%$.

Asset size, capital strength, profitability and liquidity risk are statistically significant in explaining Indonesian commercial banks efficiency from 20042009 but only asset size, profitability and liquidity risk that have correlation to technical efficiency. This findings are supported with the fact that Indonesian banks experienced major mergers and acquisitions which make them becomes bigger yet being driven to be more efficient by the acquiring bank and the higher the liquidity risk is also contributing to manage operations more efficiently. In the same time, because of merger and acquisition being done to fulfill the requirement of the Indonesian government is the reason why capital strength is not significantly related to technical efficiency. Moreover, that returns earned by banks in Indonesia were not coming from performing intermediary role to the business for the sake of economic growth which made profitability is negatively correlated with technical efficiency.

\section{REFERENCES}

Al-Tamimi, H.A.H. 2006. The Determinants of the UAE Commercial Banks' Performance: A Comparison of the National and Foreign Banks. Journal of Transnational Management, 10(4): $35-47$.

Avkiran, N.K. 1999. An Application Reference for Data Envelopment Analysis in Branch Banking: Helping the Novice Researcher. International Journal of Bank Marketing, 17(5): 206-220.

Bank Indonesia. 2010. Kajian Stabilitias Keuangan (KSK). Jakarta: Bank Indonesia.

Banker R.D., Charnes, A. \& Cooper, W.W. 1984. Some Models for Estimating Technical and Scale Inefficiencies in Data Envelopment Analysis. Management Science, 30(9): 10781092.

Barr, R.S., Killgo, K.A., Siems, T.F. \& Zimmel, S.A. 2002. Evaluating the Productive Efficiency and Performance of U.S. Commercial Banks. Managerial Finance, 28(8): 3-25.

Barry, T.A., Dacanay, S.J., Lepetit, L. \& Tarazi, A. 2008. Ownership Structure and Bank Efficiency in the Asia Pacific Region, Woking Paper, University of Limoges.

Berger, A.N. \& Mester, L.J. 2003. Explaining the Dramatic Changes in Performance of U.S. Banks: Technological Change, Deregulation and Dynamic Changes in Competition. Journal of Financial Intermediation, 12(1): 57-95.

Berger, A.N., Humphrey, D.B. 1997. Efficiency of Financial Institutions: International Survey and Directions for Future Research. European Journal of Operational Research. 98(2): 175212. 
Berger, A.N., Demsetz, R. \& Strahan, P. 1999. The Consolidation of The Financial Services Industry: Causes: Consequences and Implications for The Future. Journal of Banking and Finance, 23(2-4): 135-194.

Bisnis Indonesia. 2010. Arah Bisnis dan Politik 2010. Jakarta: Bisnis Indonesia.

Chan, S.G. 2011. Technical Efficiency of Commercial Banks in China: Decomposition into Pure Technical and Scale Efficiency. International Journal of China Studies, 2(1): 27-38.

Charnes, A., Cooper, W.W. \& Rhodes, E. 1978. Measuring the Efficiency of Decision Making Units. European Journal of Operational Research. 2(6): 429-444.

Cooper, W.W., Seiford, L.M. \& Zhu, J. 2004. Data Envelopment Analysis: History, Models and Interpretations, in Handbook on Data Envelopment Analysis, eds W.W. Cooper, L.M., Seiford and Zhu, J., Chapter 1, 1-39, Boston: Kluwer Academic Publishers.

Drake, L.M., Hall, M.J.B. \& Simper, R. 2006. The Impact of Macroeconomic and Regulatory Factors on Bank Efficiency: A Non-Parametric Analysis of Hong Kong's Banking System. Journal of Banking and Finance. 30(5): 14431466.

Galagedera, D.U.A \& Edirisuriya, P. 2004. Performance of Indian Commercial Banks (1995-2002): An Application of Data Envelopment Analysis and Malmquist Productivity Index. South Asian Journal Management, 12(2): 52-74.

Hadad, M.D., Santoso, W., Mardanugrah, E. \& Ilyas, D. 2003. Analisis Efisiensi Industri Perbankan Indonesia: Penggunaan Metode Non Parametrik Data Envelopment Analysis (DEA). Research Paper No. 7, Bank Indonesia.

Hadad, M.D., Hall, M.J.B., Kenjegalieva, K., Santoso, W., Satria, R. \& Simper, R. 2008. Efficiency in Indonesian Banking: Recent Evidence. Working Paper No.13, Loughborough University.

Hauner D. 2005. Explaining Efficiency Differences among Large German and Austria Banks. Applied Economics, 37(9): 969-980.

Hermes, N. \& Vu, T.H.N. 2008. The Impact of Financial Liberalization on Bank Efficiency: Evidence from Latin America and Asia, Applied Economics. 42(26): 1466-4283.

Havrylchyk, O. 2006. Efficiency of the Polish Banking Industry: Foreign Versus Domestic
Banks. Journal of Banking and Finance, 30(7): 1975-1996.

ICRA Indonesia. 2010. Assessing the Impact of Bank Indonesia's New Policy: Linking Reserve Requirement Ratio to Banks' Loan-to-Deposit Ratio.

Bank Indonesia. 2010. Indonesian Banking Booklet (IBB). Jakarta: Bank Indonesia.

Bank Indonesia. 2010. Indonesian Banking Statistics (IBS) Volume 8 No 6. Jakarta: Bank Indonesia.

Investor Magazine. February 2011. Peta Perbankan 2011, XIII(24): 103-104.

Isik, I. \& Hassan, M.K. 2002. Technical, Scale and Allocative Efficiencies of Turkish Banking Industry. Journal of Banking and Finance. 26(4): 719-766.

Paradi, J.C. \& Schaffnit, C. 2004. Commercial Branch Performance Evaluation and Results Communication in A Canadian Bank - A DEA Application, European Journal of Operational Research, 156, 719-735.

Pasiouras, F. 2008. Estimating The Technical and Scale Efficiency of Greek Commercial Banks: The Impact of Credit Risk, Off-Balance Sheet Activities, and International Operations, Research in International Business and Finance. 22(3): 301-318.

Pasiouras, F., Sifodaskalakis, E. \& Zopounidis, C. 2007. Estimating and Analysing the Cost Efficiency of Greek Cooperative Banks: An Application of Two Stage Data Envelopment Analysis. Working Paper Series No. 2007.12, University of Bath.

Permono, I.S. \& Darmawan. 2000. Analisis Efisiensi Industri Perbankan di Indonesia (Studi Kasus Bank-Bank Devisa di Indonesia Tahun 19911996). Jurnal Ekonomi dan Bisnis Indonesia, 15(1): 1-13.

Putri, V.R. \& Lukviarman, N. 2008. Performance Measurement of Commercial Banks Using Efficiency Approach: A study to Publicly Listed Banks in Indonesia. Jurnal Akuntansi dan Auditing Indonesia, 12(1): 37-52.

Saad, W. \& Moussawi, C.E. 2009. Evaluating the Productive Efficiency of Lebanese Commercial Banks: Parametric and Non-Parametric Approaches. International Management Review, 5(1): 5-19.

Schawb, K. 2010. Global Competitiveness Index 2010. Geneva: World Economic Forum. 
Shenkar, O. \& Luo, Y. 2004. International Business. First Edition. Singapore: Wiley Higher Education.

Sufian, F. 2007. Bank Mergers Performance and The Determinants of Singapore Banks's Efficiency. Gajah Mada International Journal of Business, 9(1): 19-39.

Sufian, F. 2010. Modelling Banking Sector Efficiency: A DEA and Time Series Approach. Ekonomika, 89(2): 111-119.

Suseno, P. 2008. Analisis Efisiensi dan Skala Ekonomi Pada Industri Perbankan Syariah di Indonesia. Journal of Islamic and Economics, 2(2): 3555.

Suzuki, Y. \& Sastrosuwito, S. 2011. Efficiency and Productivity Change of the Indonesian Commer- cial Banks. International Proceedings of Economics Development and Research, 7: 10-14.

Tahir, I.M., Abu Bakar, N.M. \& Haron, S. 2009. Estimating Technical and Scale Efficiency of Malaysian Commercial Banks: A Non-Parametric Approach. International Review of Business Research Papers, 5(1): 113- 123.

Usman, M., Wang, Z., Mahmood, F. \& Shahid, H. 2010. Scale Efficiency in Banking Sector of Pakistan. International Journal of Business and Management, 5(4): 104-116.

Zhu. J. 2009. Quantitative Models for Performance Evaluation and Benchmarking: Data Envelopment Analysis with Spreadsheets. Second Edition. New York: Springer. 